\title{
Strategi Marketing Lembaga Pendidikan Islam "The Outstanding School Of Muhammadiyah Jawa Timur" Di SMP Muhammadiyah 12 Sendangagung Paciran-Lamongan
}

\author{
Ahmad Muazar Habibi ${ }^{1)}$ \\ Akhtim Wahyuni $*^{2)}$. \\ Program Studi Manajemen Pendidikan Islam, Universitas Muhammadiyah Sidoarjo, Indonesia \\ Jl. Majapahit, 666 B, Sidoarjo \\ Program Studi Manajemen Pendidikan Islam, Universitas Muhammadiyah Sidoarjo, Indonesia \\ Jl. Majapahit, 666 B, Sidoarjo
}

\author{
Habibimuazar629@gmail.com @umsida.ac.id \\ awahyuni@umsida.ac.id@umsida.ac.id
}

\begin{abstract}
The Marketing Strategy Islamic Education Institution is important as a school for The Outstanding School of Muhammadiyah East Java. Research at SMP M 12 Sendangagung. Problem formulation: (1) How is the Marketing Strategy of SMP M 12 Sendangagung? (2) What are the Supporting Factors of Marketing Strategy at SMP M 12 Sendangagung? (3) What Are the Inhibiting Factors of Marketing Strategy at SMP M 12 Sendangagung? Descriptive approach qualitative method. Data collection techniques: observation, interviews, and documentation. The research results of SMP (Middle School) Muhammadiyah 12 Lamongan are marketing strategies by improving quality, applying mix marketing strategies 7P (Product, Price, Promotion, Place, People, Process, and Physical Evidence. Supporting factors of marketing strategy: (a) SMP M 12 Sendangagung in the area of Islamic boarding schools Al Islah, (b) The daily language of Arabic and English students, (c) Strategic area, (d) Promotion through

internet media or websites; (e) Strategic places. Inhibiting factors: (a) Lack of human resources for promotion; ( b) Traffic, (c) Expansion, (d) Competitive school locations are many, (e) Administrative staff are only administration staff.
\end{abstract}

Keywords: Strategy; Marketing; Institution; Education; Islam.

\section{Latar Belakang Umum}

\section{A. PENDAHULUAN}

Sudah menjadi realitas di masyarakat, bahwa persaingan antar sekolah saat ini semakin kompetitif. Hal sepertiini tentunya menjadi sinyal yang positif untuk meningkatkan kualitas penyelenggaraan pendidikan untuk menggali keunikan dan keunggulan sekolahnya agar dibutuhkan dan diminati oleh pelanggan jasa pendidikan. Tumbuhnya sekolah unggulan dengan kurikulum berstandar Internasional serta munculnya sekolah negeri dan swasta yang menawarkan keunggulan sarana prasarana, bahkan dengan biaya yang mudah terjangkau, dapat menambah maraknya kompetensi pendidikan.

"Marketing menjadi sesuatu yang mutlak harus dilaksanakan oleh sekolah, selain ditujukan untuk memperkenalkan, fungsi marketing di lembaga pendidikan adalah untuk membentuk citra baik terhadap lembaga menarik sejumlah calon siswa." ${ }^{1}$ Maka dari itu perlu diadakannya strategi marketing bagi setiap sekolah.

Di masa sekarang ini, perkembangan pendidikan semakin pesat untuk itu lembaga pendidikan harus mampu menyajikan kualitas pengembangan mutu sebagai alternatif untuk menghadapi perubahan dunia pendidikan, supayatidak menimbulkan konflik yang bergejolak (turbulent) dan ketidakpastian (uncertainly) yang dapat mengancam runtuhnya berbagai macam tatanan. ${ }^{2}$

Sekolah adalah subsistem dari sistem sosial, karena itu, sekolah atau madrasah tidak memisahkan diri dari atau terasing dari masyarakatnya. Bagaimanapun, masukan siswa dan dana adalah berasal dari masyarakat. Lebi h dari itu, di satu sisi sekolah memerlukan masyarakat dalam meyusun program yang relevan, sekaligus memerlukan dukungan dari masyarakat baik berupa calon murid/pendaftaran, maupun pembiayaan (SPP/DPP) dalam melaksanakan program sekolah, madrasah dan pesantren. ${ }^{3}$

Berdasarkan pengamatan dan penelusuran kami sejauh ini, mengenai penelitian tentang Strategi marketing lembaga pendidikan islam bisa dikatakan belum ada, namun kami menemukan penelitian 
sebelumnya yang membahas terkait dengan strategi marketing sekolah dalam upaya peningkatan kuantitas sekolah yang mempunyai relevansi untuk mendukung penelitian ini, yakni tentang strategi marketing lembaga pendidikan islam, diantaranya: EniMurwati, Jurnal yang berjudul "Strategi Marketing Islam (Studi tentang Strategi Marketing di MTs. Negeri Maguwoharjo) di UIN Yogyakarta". Strategimarketingpendidikan islam merupakan proses perencanaan, pengorganusasian, pengarahan dan pengawasan pendayagunaan sumberdaya yang dilakukan secara efesien dan efektif guna menawarkan jasa pendidikan islam. Hasil penelitian ini adalah : (1) proses Strategimarketing di MTs. N Maguwoharjo melalui beberapa tahap yaitu perencanaan, penataan, kepemimpinan, dan pengendalian. Perencanaan marketing dilakukan dengan menetapkan tujuan, strategi marketing, kebijakan, dan prosedur. (2) target marketing yang sudah dicapai di MTs. N Maguwoharjo yaitu jumlah siswa sudah terpenuhi, sekolah diliput TV sudah lebih dari $3 \mathrm{X}$ setahun dan sekolah sudah mulai dikenal masyarakat. Sedangkan target yang ingin dicapai -10 tahun ke depan yaitu menjadi sekolah pilihan dan tujuan mendapatkan siswa berprestasi akademik maupun nonakademik, dan terdapat SDM khusus Strategi marketing. (3) pendorong dari dalam (internal) Strategi marketing yaitu: SDM yang aktif dan bermoti vasitinggi, keunggulan sebagai madrasah hijau dan berprestasi, keuangan dan pembiayaan sekolah yang murah. Sedangkan dorongan dari luar (eksternal) Strategi marketing yaitu :kerjasama dan interaksi yang baik antar madrasah dengan masyarakat baik melalui media massa maupun elektronik. ${ }^{4}$

\section{Kajian Literatur Terdahulu (State of The Art)}

a. Eni Murwati, tesis yang berjudul "Strategi Marketing Islam (Studi tentang Strategi Marketing di MTs. Negeri Maguwoharjo) di UIN Yogyakarta". Strategi marketing pendidikan islammerupakan proses perencanaan, pengorganisasian, pengarahan dan pengawasan pendayagunaan sumberdaya yang dilakukan secara efesien dan efektif guna menawarkan jasa pendidikan islam. Hasil penelitian ini adalah : (1) proses Strategi marketing di MTs.N Maguwoharjo melalui beberapa tahap yaitu perencanaan, penataan, kepemimpinan, dan pengendalian. Perencanaan marketing dilakukan dengan menetapkan tujuan, strategi marketing, kebijakan, dan prosedur. (2) Target marketing yang sudah dicapai di MTs.N Maguwoharjo yaitu jumlah siswa sudah terpenuhi, sekolah diliput TV sudah lebih dari 3X setahun dan sekolah sudah mulai dikenal masyarakat. Sedangkan target yang ingin dicapai -10tahun ke depan yaitu menjadi sekolah pilihan dan tujuan mendapatkan siswa berprestasi akademik maupun nonakademik, dan terdapat SDM khusus Strategimarketing. (3) Pendorong dari dalam (internal) Strategimarketing yaitu: SDM yang aktif dan bermotivasi tinggi, keunggulan sebagai madrasah hijau dan berprestasi, keuangan dan pembiayaan sekolahyang murah. Sedangkan dorongan dari luar (eksternal) Strategimarketing yaitu: kerjasama dan interaksi yang baik antar madrasah dengan masyarakat baik melalui media massa maupun elektronik. ${ }^{5}$

b. Sri Lestari, Jurnal yang berjudul "Strategi Marketing Sekolah Di SMA Batik 1 Surakarta". Hasilpenelitian berdasarkanMatrik SWOT adalah sebagaiberikut : 1) Strategi SO yaitu meningkatkan segmen pasar dengan promosi. 2) Strategi ST yaitu memanfaatkan SDM untuk menciptakan produk, harga dan promosi yang berbeda dari pesaing. 3) Strategi WO yaitu mengoptimalkan fungsi lahan untuk KBM berbasis IT dan berkarakter agar memiliki pelanggan loyal. 4) Strategi WT yaitu mengoptimalkan peranan SDM untuk meningkatkan mutu pelayanan terhadap pelanggan. Berdasarkan Matrik SWOT didukung data LITBANG maka strategi marketing sekolah di SMA Batik 1 Surakarta yang paling efektif adalah promosi dengan persentasi oleh alumni SMP. ${ }^{6}$

Karenanya di sekolah ini kuat dalam pelaksanaan Strategi Marketing. Mengacu pada latar belakang yang telah diuraikan di atas, maka penulis tertarik untuk melakukan penelitian dengan judul "Strategi MarketingLembaga Pendidikan Islam"The Outstanding School of Muhammadiyah Jawa Timur" di SMP Muhammadiyah12 Sendangagung Paciran-Lamongan

\section{Metode Penelitian}

\section{B. METODE PENELITIAN}

Penelitian ini menggunakan metode penelitian kualitatif dengan pendekatan deskriptif. Penelitian kualitatif dengan metode deskriptif digunakan untuk mempelajari berbagai peristiwa yang terjadi pada objek yang diteliti, aspek, gejala atau keadaan dari hasil temuan dilapangan. Metode ini menghasilkan data deskriptif berupa kata-kata tertulis maupun lisan yang dikumpulkan melalui observasi, wawancara, dan studi dokumentasi kemudian dilakukan proses analisis sehingga diperoleh kesimpulan terkait Strategi Marketing di SMP Muhammadiyah 12 Sendangagung Paciran. Penelitian ini dilaksanakan di SMP Muhammadiyah 12 Sendangagung Paciran yang beralamat di Jl. Sendangagung Paciran Lamongan Jawa Timur No. Telp. (0322) 661854 penelitian ini dilaksanakan mulai 11 Februari 2018 sampai dengan 15 April 2018.

\section{Subjek yang diteliti}

Strategi Marketing Sekolah di SMP Muhammadiyah 12 Sendang Agung

a. An a lis is Lingkungan 
$\square$ Analisis Eksternal melihat faktor Pendukung yang bisa menguntungkan organisasi.

$\checkmark$ Mampu menghambat faktor dari luar organisasi dalam persaingan marketing

$\square$ Analisis Internal melihat kekuatan yang dimiliki dalam lembaga maupun oraganisasi dalam marketing sekolah.

$\square$ Mampu meminimalisir kelemahan organisasi dalam marketing sekolah b. Implementasi Strategi, Tangggung jawab dan tugas tanggung jawab

$\square$ Perilaku yang menggambarkan motivasi, kemudian semangat kerja, penghargaan dan disiplin kerja yang tinggi.

Sumber data penelitian ini adalah kepala sekolah, wakil kepala sekolah (Wakasis), ketua Penerimaan Peserta Didik Baru (PPDB), orangtua siswa, siswa, dan bagian tata usaha terkait profil SMP Muhammadiyah 12 Sendangagung Paciran.

\section{Teknik dan Instrumen Pengumpulan Data}

Untuk memperoleh data mengenai Strategi Marketing sekolah di SMP Muhammadiyah 12 Sendangagung Paciran. Penulis menggunakan tiga teknik dalam pengumpulan data penelitian, yaitu: observasi, wawancara dan studi dokumentasi.

a. Observasi; Observasi adalah kegiatan mengamati dan mencatat segala keadaan dan kejadian dari berbagai hal yang diamati di lapangan dengan tujuan untuk memperoleh data supaya menghasilkan data yang akurat.

b. Wawancara; Metode wawancara adalah proses percakapan oleh pewawancara dengan narasumber yang telah ditetapkan untuk memperoleh informasi dan menggali data tentang Strategi Marketing sekolah dalam meningkatkan jumlah siswanya. Alat yang digunakan adalah pedoman wawancara, perekam suara, dan alat tulis.

b. Studi Dokumentasi; Teknik ini merupakan sejumlah catatan peristiwa yang sudah berlalu, bisa berbentuk tulisan, gambar, atau karya-karya dari seseorang. Studi dokumentasi diperlukan untuk mengumpulkan data- data dengan mempelajari dan mencatat bagian-bagian resmi yang terdapat di lokasi penelitian. Teknik inisaling berkaitan satu sama lain untuk memperoleh data atau informasi saat melakukan penelitian terkait Strategi Marketing sekolah di SMP Muhammadiyah 12 Sendangagung Paciran.

\section{Instrumen Penelitian}

Instrumen penelitian merupakan sebuah media yang digunakan untuk pengumpulan data, dengan tujuan untuk mempermudah selama proses penelitian. Instrumen penelitian yang digunakan adalah wawancara, hal ini untuk mendapatkan informasi secara langsung terkait Strategi Marketing sekolah di SMP Muhammadiyah 12 Sendangagung Paciran.

\section{Teknik Analisis Data}

Teknik analisis data merupakan suatu cara yang dilakukan untuk menguraikan keterangan yang telah diperoleh agar informasi tersebut dapat dipahami oleh peneliti dan juga dipahami oleh orang lain yang ingin mengetahui hasil penelitian ini. Penulis melakukan analisis data dengan menggunakan langkahlangkah sebagai berikut :

a. Proses klasifikasi data yaitu proses pengelompokkan data dari narasumber berdasarkan jawaban sumber informasi;

b. Proses kategorisasi yaitu proses pengelompokkan data berdasarkan aspek-aspek masalah pendidikan dalam hal ini aspek Strategi Marketing dalam meningkatkan jumlah siswa;

c. Proses interpretasi data yaitu proses memberikan penafsiran data/informasi yang diperoleh dari sumber data yang ada;

d. Penarikan kesimpulan yaitu proses menemukan kaitan-kaitan penting dari variabel-variabel penelitian yang ada.

\section{Uji Keabsahan Data}

Dalam pengujian data, metode penelitian kualitatif berbeda dengan kuantitatif. Ada bermacammacam cara pengujian keabsahan data dan salah satunya adalah triangulasi. Dalam riset kualitatif triangulasi menjadi sesuatu yang sangat penting untuk membantu pengamatan menjadi lebih jelas dan lebih terang, sehingga informasi menjadi lebih jernih. Triangulasi adalah proses validasi yang harus dilakukan dalam riset untuk menguji keabsahan antara sumber data yang satu dengan sumber data lainya. 


\section{Materi Penelitian}

Untuk lebih memudahkan dalam memahami dan memperoleh gambaran yang lebih jelas serta komprehensif mengenai judul tesis ini, maka dalam hal ini akan dijelaskan beberapa istilah-istilah yang terdapat dalam judul tesis ini.

\section{a. Strategi Marketing}

Penggunaan sumber daya yang secara efektif untuk mencapai sasaran dalam suatu proses sosial yang didalamnya indivisu dan kelompok mendapatkan apa yang mereka butuhkan dan inginkan dengan menciptakan, menawarkan dan secara bebas mempertukarkan produk yang bernillai dengan pihak lain. ${ }^{7}$

b. Lembaga Pendidikan Islam

Lembaga pendidikan Islam adalah sistem komplek yang menakup berbagai hal yang berhubungan dengan konsep sosial, psikologis, politik, hukum, akhlak, budi pekerti yang berdasarkkan Al-qur'an dan Alhadits.

Pendidikan dalam arti luas terbatas adalah segala usaha sadar yang dilakukan oleh keluarga, sekolah, masyarakat dan pemerintah melalui kegiatan bimbingan pengajaran dan latihhan yang diselenggarakan di lembaga pendidikan formal ( Sekolah ) non formal ( masyarakat) dan in formal ( keluarga ) dan dilaksanakan sepanjang hayat, dalam rangka mempersiapkan peserta didik agar berperan dalam berbagai kehidupan. ${ }^{8}$

c. SMP Muhammadiyah 12 Sendangagung Paciran

Obyek peneliitian dalam tesis ini merupakan lembaga pendidikan swasta yang dimiliki dan dikelola oleh yayasan Pondok pesantren Al-Islah kecamatan paciran yang penyusun jadikan sampel dalam penelitian ini untuk mengetahui sejauh mana terjadinya pergeseran apresiasi masyarakat terhadap pendidikan yang ditinjau dari perspektif manajemen pendidikan islam, yang notabenya masyarakat adalah sangat religius, apalagi paciran kabupaten lamongan yang dikenal sebagai kota santri yang tentu segala sikap dan prilakunnya akan selalu dipertimbangkan menurut ajaran agama yang dipeluknya dalam menentukan pilihan pendidikan untuk anaknya.

\section{HASIL PENELITIAN DAN PEMBAHASAN}

Dari peneilitian yang penulis buat dapat dijabarkan mengenai strategi marketing lembaga pendidikan islam di SMP Muhammadiyah 12 Sendangagung Paciran yang meliputi upaya strategi marketing sekolah tersebut guna meningkatkan mutu kualitas sekolah, faktor Pendukung dalam menentukan strategi marketing sekolah Islam di SMP Muhammadiyah 12 Sendangagung Paciran-Lamongan kepada masyarakat, serta faktor penghambat dalam menentukan strategi marketing sekolah Islam di SMP Muhammadiyah 12 Sendangagung Paciran-Lamongan kepada masyarakat.

\section{Strategi Marketing SMP Muhammadiyah 12 Sendangagung}

Strategi Marketing yang dilakukan oleh Sekolah SMP Muhammadiyah 12 Sendangagung dengan menggunakan bauran pemasaran yang terdiri atas tujuh alat marketing jasa pendidikan, yang juga dikenal dengan istilah 7P ( Product, Price, Promotion, Place, People, And Physical Evidence)

\section{a. Merencanakan Product}

Sekolah memiliki program khusus pendidikan yang telah dikembangkan dan disesuaikan dengan kebutuhan siswa.

1. Life Skill adalah pendidikan yang memberikan pembekalan dan latihan yang dilakukan secara efektif dan efisien kepada siswa. Ketua panitia PPDB mengungkapkan: "kegiatan sapa dan salam ini bermksud agar siswa membiasakan dengan orang yang lebih tua maupun sebayanya untuk bersalaman dan mengucap salam ketika bertemu." 9

Kegiatan rutinitas yang berjalan yaitu, mengaji dan berdo'a sebelum memulai pelajaran, Muhadatsah (percakapan) dengan Bahasa Arab dan Bahasa Inggris setiap pagi hari sebelum pelajaran dimulai kemudian dilanjutkan sholat Dhuha di musholah SMP Muhammadiyah 12 Sendangagung Paciran atau di masjid Pondok Pesantren Al-Islah. Setelah itu dilanjutkan dengan kegiatan sholat dzuhur berjamaah di masjid Al- Islah dengan bapak dan ibu guru beserta staff asjid secara berjamaah.

2. Moving Class; Program ini mengharuskan siswa agar bergantian dari kelas satu ke kelas yang lainya. Misalnya ketika sebelumnya berda di kelas D bisa berganti ke kelas A, maka ruangannyapun ikut berubah. Cara ini sangat efektif. Siswa kelas VIII mengatakan:

"jika siswa bosan duduk di depaan, nanti di ruangan berikutnya bisa berpindah ke belakang lagi duduknya dan tidak harus datang pagi-pagi untuk menyapu kelas"

Program ini, banyak diterapkan di Perguruan Tinggi, di SMP Muhammadiyah 12 Sendangagung Paciran masih mempraktekkan sistem duduk moving class karena bagi siswa SMP merupakan usia remja 
dimana mereka belum mampu secara total untuk bersaing dan menghadapi berkembangan zaman yang semakin dewa, dan masih terus berkeinginan mencari jati dirinya sangatlah kuat.

3. Annual project (projek tahunan karya siswa)

"Disamping untuk menghasilkan bentuk pembelajaran yang berkualitas sekolah juga harus menfasilitasi hasil karya siswa dengan mengadakan pentas seni. Adapun pentas seni terdiri dari berbagai macam penampilan dari kreativitas siswa itu sendiri berupa Band, dekorasi, teater, pidato bahasa Arab dan Bahasa Inggris serta tilawatil qur'an dan masih banyak lagi. Pentas seni siswa diadakan setelah pembagian raport kenaikan kelas yang bersamaan dengan acara open house sekolah sekaligus dijadikan sebagai media promosi sekolah terhadap masyarakat." 11

Sekolah memberikan gambaran dan wawasan kepada siswa didiknya, bhawa hasil kraya siswa sangat mahal harganya dan penting, maka siswa akan merasa bangga dan senang bahwa hasil karya ilmiahnya mampu memberikan penghargaan dan apesiasi dari bapak dan ibu guru, maupun sekolahanya.

4. Mentoring

Mentoring merupakan suatu aktifitas yang menyaring atau mengevaluasi kembali ibadah-ibadah selama satu pekaan. Kegiatan tersebut dilaksanakan sebulan sekali yaitu setiap tanggal 30 akhir bulan. Kegiatan ini diawali dengan pembukaan dan pembacaan ayat Al-Qur'an.

"Dengan mentoring siswa mampu untuk saling membangun dalam mencapai target menjadi individu yang berkepribadian lebih baik dan menjadi sarana siswa untuk berkembang sesuai kemampuannya.,12

5. Home Stay

Merupakan suatu kegiatan yang mengintegrasikan kemampuan pengetahuan siswa dan emosional siswa. aktifitas tersebut psikis anak dicantumkan dalam kegiatan Study Tour.

"kegiatan tersebut guna melatih ketahanan fisik dan mental siswa untuk menyelesaikan tugasnya dengan baik tentang apa yang ada diluar sekolah. Siswa juga dilatih disiplin diri, tanggungjwab dan kesehatan emosional. "13

9 Aman jami'in, S. Pd, M.Pd, ketua PPDB SMP Muhammadiyah 12 Sendangagung Paciran Lamongan, Hasil Wawancara, Lamongan: 1 Juni $20018{ }^{10}$ Mahendra El-Faj, siswa kelas VIII SMP Muhammadiyah 12 Sendangagung Paciran Lamongan, Hasil wawancara, Lamongan: 2 Juni $2018{ }^{11}$ Aman Jami'in, S.Pd, M. Pd, Ketua PPDB SMP Muhammadiyah 12 Sendangagung Paciran Lamongan, hasil Wawancara, Lamongan: 1 Juni $2018^{12}$ Aman Jami'in, S. Pd, M. Pd, Ketua PPDB SMP Muhammadiyah 12 Sendangagung Paciran Lamongan, Hasil Wawancara, Lamongan: 1 Juni $2018{ }^{13}$ H. Abd. Ghofur, Guru SMP Muhammadiyah 12 Sendangagung Paciran Lamongan, hasil Wawancara, Lamongan: 2 Juni 2018

Home stay yang dilakukan olehSMP Muhammadiyah 12 Sendangagung Paciran biasanya sering dilakukan di daerah Lamongan area selatan, kedumpring jawa timur dan waktunya ketika pertengahan semester akhir kelas VIII. Siswa tersebut mengunjungi lokasi tertentu dan bermalam bersama dilokasi warga setempat yang memang khusus disewakan untuk kegiatan sekolah.

6. Home Visite

Sekolah melakukan kegiatan seperti halnya kunjungan rumah ini tidak hanya dilakukan ketika seorang siswa sedang bermasalah saja, akan tetapi orang tua melihat ketika ada orang tua yang kuran apresiasif kepada anak nya. Siswa yang prestasinya cenderung menurun serta memiliki daftar hadir cukup akan dilakukan kunjungan rumah. Kegiatan ini bertujuan sebagai salah satu alternatif untuk menyelesaikan persoalan anak dan keluarga.

7. Problem solving

"program ini merupakan program yang implementasinya untuk membantu siswa dalam memecahkan masalah yang dihadapi siswa, baik kesulitan belajar atau pekerjaan Rumah (PR), pengulangan materi bahasan sekolah yang masih belum sepenuhnya dipahami. Melalui guru BK melakukan pemecahan masalah terhadap siswa. Kegiatan ini dilakukan dengan berbagai cara yakni melalui kegiatan sharing bersama maupun secra individu.,"14

Upaya-upaya sekolah yang dimaksud diatas adalah sebagai berikut:

a. Diadakan evaluasi belajar siswa secara rutin

b. Model pembelajaran dengan pendekatan logika fisika tanpa rumus, matematika yang asik dan menyenangkan

c. Konsep REC (Remedial, Enrichment)

\section{b. Menentukan Harga/ Biaya (Price)}

Mutu Lembaga Pendidikan akan mendapat kepercayaan dari pelayanan yang disajikan secara nyata kepada orangtua siswa maupun siswanya sendiri. Selain hal itu dapat dilihat dari hasil prestasi siswa. Sekolah 
ini juga menawarkan harga yang cukup sedang untuk kalangan masyarakat Lamongan, khususnya masyarakatppaciran, Ketua PPDB yang mengemukakan:

Dalam menentukan biaya bagi siswa, bagian keuangan membuat draff rincian biaya siswa, sesuai dengan hasil kesepakatan bersama dengan lembaga dan yayasan. Yang mana biaya tersebut dipergunkan untuk proses pembelajaran dalam 1 tahun, namun dalam tahun berikutnnya, biasanya mengalami perubahan dari uang gedung, uang pangkal, dan uang spp perbulanya.

Tabel 4.1

BIAYA PPDB

\begin{tabular}{|c|c|c}
\hline No & Jenis Biaya & \multicolumn{1}{c}{ Harga } \\
\hline 1. & Uang Pangkal dan Gedung & Rp. 400.000,- \\
\hline 2. & SPP Sekolah Bulan Pertama & Rp. 65.000,- \\
\hline 3. & Kegiatan Awal Tahun & Rp. 50.000,- \\
\hline 4. & Tes Kesehatan & Rp. 20.000,- \\
\hline 5. & Seragam Sekolah & Rp. 365.000,- \\
\hline 6. & Atribut Sekolah dan Blocknote & Rp. 45.000 \\
\hline 7. & Kegiatan Ekstrakulikulier & Rp. 35.000,- \\
\hline & JUMLAH & Rp. $980.000,-$ \\
\hline
\end{tabular}

\section{c. Melakukan Promosi (Promotion)}

Promosi merupakan suatu bagian yang terpenting dalam marketing lembaga pendidikan Islam, khususnya untuk sekolah dalam Lingkup Pondok Pesantren. Sesuai dengan pendapat kepala sekolah. Adapun terkait dengan upaya marketing:

\section{Promosi secara Langsung (dari siswa)}

Promosi biasanya diperuntukkan dan digencarkan bagi siswa SD atau MI sekitar wilayah Sendangagung Paciran. Pendekatan tersebut dilakukan karena masih berada dalam satu wilayah, sehingga siswa SD atau MI meneruskan pendidikan ke jenjang pendidikan yang lebih tinggi di SMP Muhammadiyah 12 Sendangagung Paciran. Upaya lain sekolahpun secara rutin menyebarkan surat edaran dan brosur SMP Muhammadiyah 12 Sendangagung Paciran dsampaikan ketika pembagian rapot kepada wali murit yang hadir saat itu.. Ada tim promosin membagikan SMP Muhammadiyah 12 Sendangagung Paciran yang membuka stand dan membagikan souvenir hasil karya siswa SMP Muhammadiyah 12 Sendangagung Paciran untuk dibagikan kapada siswa SMP Muhammadiyah 12 Sendangagung Paciran dan santri pondok Pesantren Al-Islah.

2. Promosi melalui lembaga dan Sekolah

Kegiatan lainnya yang dilakukan sekolah yaitu dengan mengadakan open house. kegiatan tersebut secara umum dibuka untuk guru, siswa, karyawan maupun wali murid besrta masyarakat yang ingin berkunjung ke sekolah. Diatara kegiatan ini terdiri dari Pentas seni atau panggung gembira, bazar aneka makanan dan minuman, drumb band, lomba nyanyi, lomba tahfidz, lomba pidato bahasa Arab dan Bahasa Inggris, tilawah dll. Selain itu bagi para calon wali murid yang akan bertanya mengenai SMP Muhammadiyah 12

Sendangagung Paciran.

3. Promosi dengan melalui Media Cetak

Promosi melalui media cetak juga dimanfatkan oleh SMP Muhammadiyah 12 Sendangagung Paciran. Hal tersebut terdiri dari banner, brosur, dan Spanduk dan disebarluaskan dari pihak sekolah ketika penerimaan raport siswa. Akan tetapi sekolah hanya hanya menyebarluaskan brosur didalam area SMP Muhammadiyah 12 Sendangagung Pacirandan santri Pondok Pesantren Al-Islah. Hal tersebut dilakukan karena masih minimnya sumber daya manusia dalam bidan marketing. Selain itu pemasangan spanduk juga terbatas pada sekitar wilayah Sendangagung saja. Pihak sekolah tidak begitu gencar dalam mempromosikan keluar sekolah wilayah Sendangagung Paciran namun hanya dengan meningkatkan mutu kualitas dalam melakukan marketing.

\section{Promosi dengan melalui media Online}

Sekolah mampu memanfaatkan media online sebagai media promosi modern. Media yang bisa digunakan sekolah adalah website yang berisi kejadian-kejadian yang penting di SMP Muhammadiyah 12 Sendangagung Paciran yang bekerja sama dengan Pondok Pesantren Al-Islah, kegiatan siswa, prestasi siswa, lokasi, kegiatan sosial yang dilakukan oleh semua unit SMP Muhammadiyah 12 Sendangagung Paciran. Media website yang dimiliki sekolah sudah terpusat dari Pondok Pesantren Al-Islah. Dari website tersebut terdapat artikel-artikel yang bermanfaat untuk mendukung kegiatan Pondok Pesantren Al-Islah dari semua unit keseluruhan. 


\section{d. Tempat / Lokasi ( Place )}

SMP Muhammadiyah 12 sendangagung Paciran bertempat di Jalan Sendangagung Kecamatan Pacirandalam satu wilayah dengan pondok pesantren Al islah sendangagung. Tempat tersebut sangat strategis dan asri dengan pepohonan yang rindang dan di tepi jalan Raya yang menghubungkan jalan kabupaten.

Tempat berdirinya gedung SMP Muhammadiyah 12 Sendangagung Paciran tergolong lokasi yang cukup nyaman, hal ini terlihat dari letak posisinya yang berada di tepi jalan raya sehingga alat transportasi pun mudah dijangkau, selain itu juga dekat dengan area yang masih belum padat penduduk sehingga siswa nyaman untuk belajar di lembaga Pendidikan Islam tersebut.

Marketing Lembaga Pendidikan Islam, bahwasanya pemilihan lokasi harus dengan mempertimbangkan beberapa aspek diantaranya Visibilitas, lalu lintas, akses, ekspansi, sarana dan prasarana, tempat parkir, persaingan dan lingkungan yaitu:

1. Visibilitas, sekolah terlihat dengan jelas keberadaan fisiknya karena jarak antara gedung yang satu dengan gedung yang lainya dan dengan jarak ke parkiran kurang lebig $50 \mathrm{M}$. Gerbang pun selalu tertutup rapat yang tampak dari luar mushola SMP Muhammadiyah 12 Sendangagung Paiciran.

2. Lalu Lintas, karena berjarak 3 KM dari jarak Jalan Raya Deandles arah Surabaya Tuban ketika pagi dan sore keadaan lalu lintasnya tidak begitu ramai lancar oleh angkutan umum yang lalu lalang.

3. Akses, aksesnya sulit dijangkau dengan angkutan umum, jarak dengan jalan raya kurang lebih 3 KM.

4. Ekspansi, ketersediaan lahan untuk kemungkinan perluasan bangunnan sudah sangat minim sekali, karena sudah digunakan untuk perluasan asrama pondok.

5. Ruang dan sarana belajar yang memadai.

6. Tempat parkir yang luas dan aman.

7. Persaingan, lokasi sekolah pesaing cukup banyak, hal ini bisa dilihat dengan membuka dari google map yang ada MTS dan SMP Muhammadiyah Pondok Modern, Mts, serta SMP Muhammadiyah Pondok Karangasem, MTS NU, dan SMP Negeri Paciran.

8. Lingkungan, lingkungan sangat kondusif karena lokasi kelas cukup jauh dari Jalan Raya dimana siswa bisa belajar dengan tenang tanpa terdengar suara kebisingan kendaraan bermotor yang berlalu lalang.

9. Peraturan pemerintah, berdasarkan dokumentasi yang diberikan oleh sekolah, sekolah telah terakreditasi A sejak 2009 dan memiliki N.I.S yaitu 20506400 serta N.S.S 202050720019.

\section{e. SDM ( People )}

Sumber daya manusia disini adalah keseluruhan pegawai yang bekerja di lembaga SMP Muhammadiyah 12 Sendangagung Paciran Lamongan meliputi tenaga pendidik (guru) dan kependidikan (T U ), Satpam, dan Cleaning Service.

Adapun persyaratan umum yang telah ditetapkan oleh lembaga adalah :

1. Muslim atau Muslimah

2. Berakhlak Islami

3. Sanggup bekerja Full Time

4. Sabar dan Ramah

5. Berkemauan Keras untuk selalu meningkatkan wawasan

6. Energik

7. Mampu berkomunikasi dengan baik

Sedangkan Persyaratan yang Khusus adalah :

8. Pendidikan S1 sesuai jurusan

9. Dapat membaca Al-Qur'an dengan benar dan sesuai kaidah tajwid

10. IPK Min. 3.00

11. Mampu mengoprasikan komputer

12. Berpengalaman Min. 1 Tahun / pernah mengajar

\section{f. Proses ( Prosess)}

Proses merupakan langkah yang sistematis atau tahapan yang jelas dan dapat dilakukan berulang kali dengan tujuan untuk mencapai hasil yang diinginkan. Lembaga pendidikan Islam yang memiliki strategi marketing sehingga dapat dijadikan ciri khas dari sekolah yang lainnya diwilayah Paciran. Kemudian yang menjadi pertimbangan orang tua siswa adalah biaya administrasi sekolah. Ketetapan biaya tersebut ditentukan berdasarkan musyawarah Lembaga Pendidikan tersebut. 


\section{g. Bukti Fisik}

Bukti fisik merupakan lingkungan fisik sekolah tempat dimana menyediakan jasa pada konsumen untuk berinteraksi guna mengkomunikasikan dan mendukukung peranan jasa sekolah yang ada di SMP Muhammadiyah 12 Sendangagung Paciran diantaranya :

1. Mushola

2. Perpus

3. Ruang Kelas

4. Ruang Guru

5. Ruang Kepala Sekolah

6. Ruang BP

7. Sarana Olahraga ( Lapangan )

8. Laboratorium

9. Unit Kesehatan sekolah ( UKS )

10. Kantin sekolah

Sarana prasarana tersebut sebagai pendukung proses kegiatan belajar mengajar guru, karyawan serta siswa didik. Demikianlah penjabaran terkait strategi marketing sekolah di SMP Muhammadiyah 12 Sendangagung Paciran. Berdasarkan hasil yang didapat dari tujuh bauran marketing ada kesesuaian teori marketing sebagaimana mestinya yaitu SMP Muhammadiyah 12 Sendangagung Paciran.

\section{Faktor Pendukung dalam Menentukan Strategi Marketing SMP Muhammadiyah 12 Sendangagung}

Upaya penguatan marketing yang dilakukan SMP Muhammadiyah 12 Sedangagung Paciran dikhususkan mencari calon siswa dari dalam yaituPondok pesantren Al Islah melalui santri yang mondok. Pihak Pondok pesantrenpun turut serta berkolaborasi untuk mengajak santri-santrinya yang memiliki tetangga ataupun keluarga agar nantinya melanjutkan sekolah di SMP Muhammadiyah 12 Sendangagung Paciran. Bukan hanya sekedar mencari calon siswa saja melainkan promosi dilakukan dengan menonjolkan mutu kualitas yang telah dimiliki SMP Muhammadiyah 12 Sendangagung Paciran, diantaranya:

a. SMP Muhammadiyah 12 Sendangagung Paciran berada dikawasan pondok Pesantren Al Islah.

Keberadaan SMP Muhammadiyah 12 Sendangagung Paciran berada di kawasan pondok Al Islah menjadi faktor utama yang mendukung kemajuan sekolah ini. Karena Pondok Pesantren Al Islah sudah maju ndan diakui oleh masyarakat di wilayah kecamatan Paciran Kabupaten Lamongan bahkan luar wilayah. Dibawah pimpinan pengasuh Pondok Pesantren Al Islah yakni Ustadz Dawam Sholeh yang berupaya dan bekerjasama dengan SMP Muhammadiyah 12 Sendangagung Paciran dalam memajukan dan meningkatkan kualitas siswa dari tahun ke tahun.

b. Bahasa dalam keseharian siswa atau santri dalam berkomunilkasi menggunakan bahasa Internasional seperti bahasa Arab dan Inggris dalam kesehariannya. Penggunaan bahsa asing dalam keseharian siswa ketika berkomunikasi merupakan nilai positif yang tidak dimiliki oleh sekolah lainnya. Dengan begitu para siswa akan terbiasa ketika berkomunikasi dengan orang asing. Sehingga sistem informasi bisa diperoleh dengan maksimal. c. Wilayah yang strategis dekat dengan pemukiman warga.

Lokasi SMP Muhammadiyah 12 Sendangagung Paciran berada diwilayah yang sangat kondusif, karena terletak di sekitar pemukiman warga dan mudah dijangkau. Sehingga cepat dikenal di masyarakat sekitar maupun masyarakat luar.

d. Promosi yang digunakan sudah berkembang kearah teknologi informasi yankni melalui media internet atau web site, sehingga mudah dikenal oleh kalangan luas secara cepat dan praktis.

Perkembangan teknologi yang sudah maju dan didukung dengan ilmu pengetahuan yang mumpuni sekolah menggunakan berbagai macam inovasi untuk promosi sekolah agar lebih mudah diterima masyarakat.

e. Promosi lewat website pondok al islah

Dengan adanya media sosial saat ini, sangat membantu sekali dan mempermudah bagi lembaga-lembaga pendidikan untuk memasarkan lembaga-lembaga pendidikanya dalam rangka mencari peserta didik baru dan memperkenalkan sekolah.

Terutama sekolah SMP M 12 Sendangagung, memanfaatkan momentum seperti ini untuk mengembangkan sekolah ke kanca Nasional dan Internasional guna memperkuat jaringan-jaringan lembaga kami.

f. Tempat yang strategis karena terletak didaerah yang diapit Dari faktor-faktor tersebut itulah yang akan mendukung strategi marketing sehingga bisa dilakukan untuk peningkatan kualitas yang dimiliki oleh SMP Muhammadiyah 12 Sendangagung Paciran kedepannya.

\section{Faktor Penghambat dalam Menentukan Strategi Marketing SMP Muhammadiyah 12 Sendangagung}

Dari beberapa uraian sebelumnya, upaya dalam mempromosikan dan memasarkan sekolah yang dilakukan dengan menggunakan sarana media dan pemikiran yang inovatif serta sangat menarik agar mudah 
diterima dan diminati publik melalui strategi marketing 7P tidak semuanya berjalan mulus dan tanpa hambatan, akan tetapi masih ditemukannya hambatan dalam menentukan strategi yang ada, diantaranya:

a. Kurangnya sumber daya manusia untuk promosi.

Masih perlunya sumber daya manusia untuk melakukan promosi dengan merata, karena selama ini SMP Muhammadiyah 12 Sendangagung Paciran hanya memanfaatkan promosi sekedarnya melalui santri- santrinya yang ada di pondok pesantren Al Islah Sendangagung Paciran serta siswa yang memiliki keluarga atau tetangga. Dengan begitu maka promosi kurang maksimal.

b. Lalu lintas; karena berjarak $3 \mathrm{KM}$ dari jalan raya Deandels arah Surabaya Tuban dari pagi sampai sore keadaan lalu lintas tidak begitu ramai oleh angkutan umum yang berlalu lalang.

Kondisi tersebut merupakan penghambat dari strategi marketing yang ada, karna siswa ketika harus kembali atau pulang dari sekolah sulit mencari kendaraan umum. Sehingga harus menumpang dengan kendaraan yang ada atau melintasi wilayah tersebut.

c. Ekspansi, memperbesar usaha dengan menciptakan area yang digunakan untuk mebangun fasilitas-fasilitas olahraga dan dan toko alat tulis dan mini market yang ada di dalam area sekolah selebihnya sekolah ingin menambah gedung baru tapi terhalang dana.

d. Perlunya dana tambahan untuk meluaskan lahan sekolah masih menjadi kendala dalam strategi marketing. Dikarenakan banyaknya siswa yang berminat sekolah di SMP Muhammadiyah 12 Sendangagung Paciran menjadikan lokasi yang dibutuhkan jga bertambah. Inilah yang masih menjadi dilemma dari pihak sekolah yang harus dipecahkan.

e. Lokasi, mudah dilihat dengan screnshoot dari google map yang ada MTS dan SMP Muhammadiyah Pondok Modrn, MTS, dan SMP Muhammadiyah Pondok Karangasem, MTS NU, dan SMP Negeri Paciran. Persaingan marketing tersebut menjadi faktor penghambat dari strategi yang ada, karena SMP Muhammadiyah 12 Sendangagung Paciran harus bekerja lebih giat lagi dalam membaca lingkungan pasar sekitara gar tetap menjadi sekolah yang memiliki keunggulan dari sekolah lain.

f. SDM kurang Staff administrasi yang terdapat di SMP Muhammadiyah 12 sendangagung Paciran, yaitu staff tata Usaha saja, karena Staf Tata Usaha tersebut juga merupakan tenaga pendidik.Masih dibutuhkannya perekrutan untuk staff TU dengan memiliki syarat kualifikasi yang memenuhi, agar ttugas yang dijalankan nanti nya bisa maksimal.

\section{Kesimpulan}

Berdasarkan hasil penelitian pada pembahasan yang telah diuraikan pada bab sebelumnya dapat disimpulkan bahwa secara keseluruhan implementasi marketing lembaga pendidikan islam yang menjadi obyek penelitian di SMP Muhammadiyah 12 Sendangagung telah berjalan dengan cukup baik. Beberapa hasil penelitian didapatkan hasil penelitian sebagai berikut:

1. Strategi Marketing yang dilakukan oleh Sekolah SMP Muhammadiyah 12 Sendangagung dengan menggunakan bauran pemasaran yang terdiri atas tujuh alat marketing jasa pendidikan, yang juga dikenal dengan istilah 7P ( Product, Price, Promotion, Place, People, And Physical Evidence)

2. Faktor pendukung dalam menentukan strategi marketing SMP Muhammadiyah 12 Sendangagung meliputi: keberadaan Sekolah SMP Muhammadiyah 12 Sendangagung berada dikawasan Pondok Pesantren Al-Islah, bahasa keseharian siswa dalam berkomunikasi dengan menggunakan Bahasa Inggris dan Bahasa Arab, Wilayah yang strategis dekat dengan pemukiman warga, Pelaksanaan promosi yang dilaksanakan hanya dengan pembuatan spanduk sekolah, website, dan brosur.

3. Faktor Penghambat dalam Menentukan Strategi Marketing SMP Muhammadiyah 12 Sendangagung meliputi: Kurangya ketersediaan SDM yang terlibat dalam pelaksanaan promosi dan kehumasan sehingga kegiatan marketing terhambat, lalu lintas yang masih terbatas karena sulitnya kendaraan umum yang lalu lalang, ketersediaan lahan guna menambah gedung yang baru dan lahan parkir yang masih kurang serta lokasi sekolah pesaing cukup banyak, serta kurangnya staff SDM yang terdapat di SMP Muhammadiyah $12 \mathrm{Se}$ ndangagung

Paciran yakni staff TU sehingga merangkap sebagai akademik keuangan dan marketing.

\section{E. Ucapan Terimakasih}

Dengan kerendahan hati, penulis menyadari sepenuhnya akan kemampuan dan kekurangan dalam penyusunan laporan ini. Oleh karena itu, penulisan ini tidak lepas dari bantuan, bimbingan, saran serta motivasi semua pihak baik langsung maupun tidak langsung dalam membantu penyusunan Jurnal ini. Oleh karena itu, pada goresan tinta ini, penulis ingin mengucapkan terima kasih dengan penghargaan yang setinggitingginya kepada yang terhormat:

1. Milatur Rusdiana, Amd. Keb, selaku istri yang senantiasa berjuang menemani dan membantu banyak hal dalam menyelesaikan tesis ini, baik semangat maupun waktunya. 
2. Buah hati kami tercinta yang akan hadir ditangah keluarga sebagai penyemangat dalam penyelesaian penelitian ini.

3. Ibunda kami tercinta yang telah memberikan ridho ,do'a dan bimbinganya atas masa depanan kami.

4. Abah dan ibuk, selaku Keluarga baru saya yang juga memberikan dorongannya supaya saya menyelesaikan Jurnal ini.

Penulis menyadari bahwa, Jurnal ini masih banyak terdapat kesalahan dan jauh dari kesempurnaan. Demikian Jurnal ini penulis buat, semoga partisipasi dan amal baik semua pihak diterima dan dibalas Allah SWT. Harapan penulis semoga laporan ini bermanfaat bagi semua pihak. Amin

1. Muhaimin, dkk., Manajemen, 2009) h. 101.

2. Aan Komariah dan Triatna, Visonary Leadership: Menuju Sekolah Efektif, ( Jakarta: PT. Bumi Aksara, 2005)h. 29.

3. Syafrudin, Manajemen Lembaga Pendidikan Islam, (Jakarta: PT. Ciputat Press, 2005) h. 272.

4. Eni Murwati,“ Manajemen Pemasaran Islam (Studi tentang Manajemen Pemasaran di MTs. Negeri Maguwoharjo ”, Tesis, ( Yogyakarta: UIN Sunan Kalijaga, 2017 ).

5. Sri Lestari, "Strategi Pemasaran Sekolah Di SMA Batik 1 Surakarta",Tesis, (Surakarta:UniversitasMuhammadiyah Surakarta, 2011).Tim Dosen Administrasi Pendidikan, Manajemen Pendidikan, ( Bandung: Alfabeta, 2013 ), h.. 337.

6. Ramayulis, Ilmu Pendidikan Islam, ( Jakarta : Kalam Mulia, 1994 ), h. 18.

7. Aman jami'in, S. Pd, M.Pd, ketua PPDB SMP Muhammadiyah 12 Sendangagung Paciran Lamongan, Hasil Wawancara, Lamongan: 1 Juni 20018

8. Mahendra El-Faj, siswa kelas VIII SMP Muhammadiyah 12 Sendangagung Paciran Lamongan, Hasil wawancara, Lamongan: 2 Juni 2018

9. H. Abd. Ghofur, Guru SMP Muhammadiyah 12 Sendangagung Paciran Lamongan, hasil Wawancara, Lamongan: 2 Juni 2018

10. Hariyati, S.Pd, Guru BK SMP Muhammadiyah 12 Sendangagung Paciran Lamongan, Hasil Wawancara, Lamongan: 1 Juni 2018 